\title{
Education for Critical Citizen Action: An example from a course on 'Media and Society'
}

\author{
Wang, Huei Lan $\bowtie$ \\ Nan Hua University, Taiwan (hlwang@nhu.edu.tw)
}

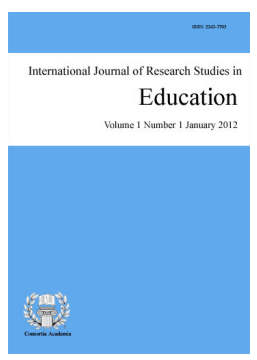

Accepted: 30 August 2018 Online ISSN: $2243-7711$

OPEN ACCESS

\section{Abstract}

In today's dynamic social and mobile media environments, developing students' critical consciousness has become a significant challenge for educators in media literacy. To meeting this challenge, this paper presents discusses how Critical Pedagogy can be introduced into university-level media literacy courses and exemplifies through an account of a general education course in Media and Society. Through classroom work (such as reflective journals, speech messaging data collection and analysis, as well as website discussions), in-depth interviews, and classroom observation, we analyze the impact of personal values on the counterculture's production of media to meet media literacy education's curriculum design demands and teaching efficacy standards. The classroom results presented in this paper, while showing an enhancement of students' media literacy critical thinking skills and sensitivity towards social issues concludes that the propensity to address social issues through concrete actions continues to be limited.

Keywords: media literacy; critical pedagogy; critical consciousness; citizenship education 


\section{Education for Critical Citizen Action: An example from a course on 'Media and Society'}

\section{Introduction}

In recent years alternative media channels have blossomed in Taiwan, and issues brought into focus by these media have rapidly proliferated seemingly out of nowhere. Alternative media are not controlled or pressured by organized cultural, private sector, or public goals and have decentralized the transmission of information. More importantly, by challenging the long-term control of mainstream media, alternative media have highlighted multiple concerns about social issues and how issues are identified, have promoted the growth of citizen power, and have therefore now become a significant concept in media literacy education.

The purpose of media literacy education is to cultivate a critical mind-set of liberation and empowerment that prepares students to become citizens willing to engage in democratic activities (Cheng, 2012). Tsai (2011) emphasizes that media literacy education involves life-long learning, participation in social activities, citizen responsibilities, and acquiring the behaviors appropriate for different social situations. The audience, hitherto the receivers of media information, becomes the producers of media awareness that appear in community activities (Jenkins, Clinton, Purushotma, Robison, \& Weigel, 2006). The use of media resources and production of media content that reflects individual perspectives, are indicators of the degree of citizen participation and demonstrate the impact of media literacy education. The core values of media literacy education include citizens' connection with, criticism of, and access to media messages. These core values are the foundation for citizen journalism, and students start to see how their own world connects with critical social issues currently facing the public.

Following the publication of the "Media Literacy Education Policy White Paper", media literacy education has attracted much attention, but it is evident that there is a range of foci and perspectives, and generally, there is not so much emphasis on citizen journalism. Rather, the focus is usually on media critical literacy and reflection from the audience's perspective. However, we believe that the purpose of media literacy education is to produce real practices based on critical thinking. In this paper, we demonstrate this view and how it can be implemented by an analysis of the thinking and actions of students enrolled in a liberal arts course called 'Media and Society' using an action research approach based on the theories of liberation and empowerment proposed by Freire (2003), Giroux (1994) and Masterman (1985).

\section{Literature Review}

\subsection{The Theoretical Basis of Critical Citizen Action}

The practice of critical citizen action originates in one's own consciousness. Freire emphasizes that the critical education process is not the top-down cramming of education but rather a process whereby learners can regain their subjectivity by building up their own knowledge; an awakened awareness arises to challenge existing objects (Freire, 2003). A problem-posing approach to education raises students' awareness process (Chang, 2010). The teacher as a transformative intellectual (Giroux, 1988) guides students to think or question their belonging in the world, and this becomes the beginning of critical action in practice. Questions related to the social environment are linked to developing conscious awareness in citizen identification, and this becomes the basis for civil action.

Critical pedagogy concepts focus on participation and liberation by emphasizing 'the language possibility' which is the sender's message being interpreted in multiple ways by its intended receiver. These concepts include liberation, empowerment, introspection, and communication that center on the "subject status" in its "situational awakening" by focusing on the reality hidden beyond the subject's own world. Freire (2003) encourages students to think about the control of cultural authority, social relationships and power function systems, and to reorganize 
their views of relationships in the world. Applying 'liberation' and 'empowerment' educates people to see and examine the process of media transmission critically. The ultimate purpose is to equip everyone with the characteristics of effective citizenship so that the ideal of people's sovereignty can be realized (Freire, 2003).

These concepts and actions of empowerment are similar to what media literacy education pursues, since media literacy education is empowerment-oriented and educates citizens who are equipped with critical thinking ability, who perceive and challenge constraints, and who are in control of their own awareness of media representation. This is similar to the theoretical concepts of 'critique' and 'action' in critical pedagogy (Shor, 2012), but different from critical pedagogy, media literacy education is based on the process of change: from self to recognition, analysis, introspection, and then finally to action in a narrow perspective (as shown in Figure 1, Wu \& Chen, 2007, p. 219). Nevertheless, this change process also emphasizes the importance of practice and action in social critiques. Livingstone (2004), connecting critical pedagogy education with media literacy education, stresses the cultivation of individual critique and introspection, but he also argues that, based on his analysis of social structures, now is the best time to critique the status quo and take action. Following Livingstone, media literacy has not merely addressed the limitations of recognition or analysis but has also engaged with the social practice of communication between media analysis in the classroom and the outside world (Wu \& Chen, 2007, p. 219).

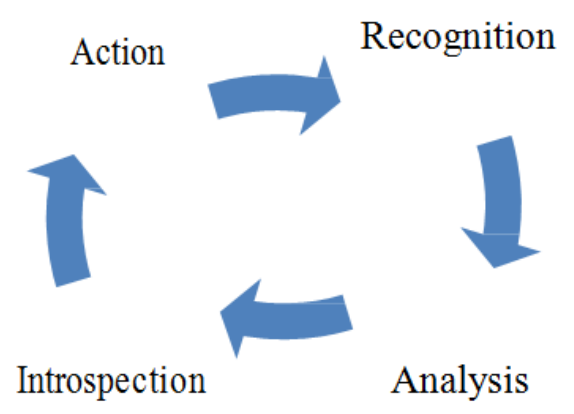

Figure 1. The structure of empowerment-oriented critique in media literacy education

\subsection{An Educational Strategy Based on Critical Pedagogy}

A review of studies in Taiwan and abroad on media literacy education and of discussions on media literacy theories and teaching methods reveals that program designs usually entail disrupting the traditional lecture format and incorporating the experiences of teachers and students (Bazalgette, 1997; Brown, 1991, 1998; Buckingham, 1990; Consdiine \& Haley, 1999; Livingstone, 2004; Kubey, 1998; Masterman, 1980, 1985, 1997). Moreover, some literature and discussion on critical literacy (Young, 1980; Meyers, 1986; Stice, 1987; Kitchener, 1986) support participation in public service media as an alternative forum to the mainstream media as this provides an opportunity for the oppressed to challenge their oppressors and speak on their own terms. The teaching methods encourage students' participation and their transformation from being media consumers into active citizen 'narrators' as subjects of themselves (Livingstone, 2003). However, few studies combine critical pedagogy/media literacy with a discussion of citizen actions, and the issues of course design and teaching efficacy receive even less attention. On the other hand, the teaching strategies of critical pedagogy have been widely discussed (Freire, 2003; Giroux, 1988; Livingstone, 2004; Shor, 2012; Hooks, 1994), and we shall analyze their relevance for media literacy education.

Asking questions as a teaching method - A genuine learner should begin by asking a question rather than receiving transmitted knowledge. Freire (2003) suggests that students should develop knowledge on their own rather than being taught what it means or what they should do. In a structured classroom environment, the habitual relationship between teachers and students constrains the roles of the controller and the controlled. The 
traditional silent learning culture prevails in 'banking education', and a top-down, cramming-oriented educational system cannot challenge unfair societal structures and generate multiple critical perspectives. By posing questions, learners can deconstruct and dismantle the traditional top-down teaching method. By questioning familiar situations, students can reflect on their original values within a subjective knowledge structure. They can subsequently connect to situational questions, expressing doubts and engaging in critical thinking. An educational method based on questioning asserts that people should critically examine the world they belong to. This process enables the transformation of reality. Its purpose is to engage students so that they become critical explorers who can communicate with others. Through a sustained process of questioning and introspection, they become subjects.

The interaction and dialogue teaching method - Giroux (1988) suggests that teachers should evolve into transformative intellectuals, as critical, involved and knowledgeable elites. The role of the teacher is not only that of the deliverer, constructor, political doer and transformer of the social structure in terms of knowledge and value, but also that of co-coordinator. Breaking from tradition, teachers and students should jointly build democratized relationships wherein they attempt to understand each other, brainstorm and share experiences. Freire (2003) had described the demise of the teacher-student relationship entailing the-teacher-of-the-student and the-student-of-the-teacher. A new and equal relationship has evolved through the dialogue between the student-teacher and teacher-student. They demonstrate respect and understanding when communicating with each other, and develop critical awareness (Freire, 2003; Giroux, 1988). Moreover, the communication extends beyond students and teachers to include their peers. Communication constitutes the learning process which not only fuels students' interests, but also generates diverse opinions and perspectives. This is the formative process of critical thinking (Shor, 2012).

Life experience - The pedagogies of Freire (2003) and Hooks (1990; 1994) both emphasize collaboration between learning and life experiences. We should start from the premise of caring for one's own experience or belonging in the world so that we can expand our focus to others, to society and the entire world through practicing the idealism of the big "I". Hooks (1990) asserts that theorization of our life experiences is related to the process of self-healing and collective liberation. There is no gap between theory and practice. Experience can make the connection clearer, promoting their mutual development. Unless students can transform their curiosity towards their life experiences into an exploration of knowledge, they will find it difficult to communicate with and construct knowledge from these experiences. The individual's cognitive in relation to society and the world within real life entails dealing with life experience. Moreover, life experience equates with students' discussion about media control and problems of oppression.

Change and action - If education only involves metaphysical discourse without action, then there is no practice. According to Freire (2003), critique combines introspection with practice. Simultaneously, it needs to gather collective strength to redress unfairness and oppression. However, it is necessary to be equipped with critical awareness before embarking on action to bring about change. The subject must realize that he/she has been oppressed and controlled. Questions initiate and lead to action. That is, the question should extend the classroom discussion into an engagement with the real world.

In media literacy education, teachers should train students to become aware of how the power structure controls the content of mainstream media (Livingstone, 2004) and as a consequence, they become aware of their own critical thinking. Thus, in education and in active practice, the media audience takes on the role of the citizen journalist reporting on issues not otherwise in the public focus. In doing so, the audience becomes another power overseeing the mass media. Groups create their own media content, which can affect the institutions and content of the media, and promote changes in media decisions (Duran, Yousman, Walsh, \& Longhore, 2008).

\section{Research Design and Questions}

Based on this literature review, this study explores theories proposed by Freire and others in a course on 
media literacy using a teaching strategy closely aligned in spirit to critical pedagogy. An action research design was developed to analyze the impact of critical thinking in relation to students' awareness, introspection and action during different learning stages. The primary question was whether students would engage in social activities and critiques of unfair social structures and practices as a consequence of the teaching/learning process in media literacy education - i.e., whether classroom learning would influence participation in activities as citizens. The study examined the teaching processes and explored students' awareness, attitudes and behaviors during their participation in classroom activities. Although, as a case study, the results cannot be generalized (Miles \& Hubermans, 1994), the analysis of a single course will, we hope, stimulate further studies and contribute to building an argument for citizen action education in Taiwan and beyond.

\subsection{Research Methods, Process, and Implementation}

Action research has been defined by Carr and Kemmis (1986, p. 162) as a mode of introspective inquiry conducted by participants in their social positions. Its purpose is to improve the rationality and justification of their practices and to promote/modify their understanding of practice and working circumstances. Teachers can improve their teaching by applying their accumulated professional experience in questioning political strategies, problems and action results (McKernan, 1991, 1996). Reflective teaching based on action research (Zeichnerk \& Liston, 1987; Bonser \& Grundy, 1988; Noffke \& Brennan, 1988) is concerned with how action research can contribute to empowerment that liberates both teachers and students (Tsai, 2004).

Problem-solving action research addresses the following questions raised by Carr and Kemmis (1986): What is the problem? How can it be solved? What can I do? In order to pursue these questions, action research requires the instigator to be both teacher and researcher.

The project began in February 2010 and ended in July 2010. The liberal arts course "Media and Society" was conducted at a Taiwanese college during the 2010 academic year's spring semester. The teacher-researcher invited 29 students who were from different departments in general education to participate in the study. The data analysis focused on the extent of students' critical awareness developed through course participation and on whether media literacy—recognition, attitudes and behavior changes resulting from participation in citizen action—impacted students' daily lives.

A three-step process of data collection was applied after obtaining the participants' permission. First, students were informed of the assignments that they were required to do to provide the research data. Second, course/assignment design, observations during course participation, teaching/learning introspection journals of teacher and students, in-depth interviews and questionnaires were completed. Third, at the end of the semester, questionnaires, in-depth interview transcripts and students' journals were analyzed to assess changes in students' understanding, attitudes and behavior after their participation. The data were analyzed and checked thematically by another academic researcher to ensure reliability.

\subsection{Teaching Strategy Design}

In view of the above-mentioned context, concepts and literature review, the strategy's aim was to assist students in achieving the following goals: reflect on the relationship between culture, society, the media and themselves; recognize their right to communicate, apply what they learned to real life situations; gain consciousness of regulated societal roles and begin to challenge the concept of social status. The course design included experience gained outside of the classroom connected to the media and community issues following the emphasis in Freire's and others' work on questioning/discussion and an experience-sharing interactive participation strategy that entailed questioning, interaction and dialogue, life experience and teaching methods for fostering action and change (Freire, 2003).

The actual course covered the relationship between society, media and individual. During the course, students learned how to express their concerns on local issues such as Typhoon Morakot - Taiwan's most 
catastrophic flood in 50 years. Such catastrophes based on real life experiences were the most effective means for fostering students' critical conscious and concern for addressing important public issues. The first part of the semester (lessons 1-6) included out of classroom "on the ground" observations of local issues; this helped students gain a good grasp of how such issues impact real people. Lessons 7-10 used a hands-on methodology in which student teams of 8-10 members performed their role as citizen journalists by on-site observing, interviewing, and filming of their subjects. Lessons 11-18 included class sessions in which local people were invited to speak directly to the class. This direct communication personified people's real problems for students. As a result, students completed with a firm critical consciousness foundation to apply when reporting on critical community issues.

The questioning method - The teacher asked questions to encourage students to think during the teaching process. This method emphasized students' own construction of their own knowledge when reflecting on the teacher's posed questions (Freire, 2003):

$>$ What kinds of interview questions should you list? Who should you interview and who can answer these questions? What is your opinion?

$>\quad$ Why should you be concerned about this issue? What is the connection between this question and you?

The questioning should start from feedback on the visit provided by the students. The teacher only assisted while students began to search for the answers based on their own experiences and data collection.

The interaction and dialogue teaching method - Shor and Freire (1987) argued that liberating classroom communication may not only increase students' understanding, but it may also generate an understanding of the social transformation process and of the social context among learners. During the teaching process of interaction and dialogue, the teacher guided students to search for information and to construct the meaning of criticism and action. This generated several discussion issues. For instance, who would benefit after the bridge repair was completed? Why should they take action and be concerned about the repair's completion? During their group discussions, some students would challenge each other, as shown in the following example of a discussion:

- S1: To whom should we address this question?

- S2: As far as I am concerned, it relates to the Chiayi City Fifth River Management Office.

- S3: I don't think they would take immediate action on this small problem. S4: Since students are too small, they will turn us away.

- S1: The less, the better. It is not my business.

- S3: Why does our teacher want us to criticize? Is it bad to not criticize?

This was how criticism developed. The teacher's role was that of a facilitator and not a director. The resulting process enabled them to acquire critical awareness. For example, though some were reluctant to challenge the situation ("Is it bad to not criticize"?), the development of their critical awareness was evident. The teacher helped students develop their own critical thinking capacities through the different perspectives discussed. Students then developed an awareness of the social citizen's role.

Life Experience - Freire (2003) and Hooks (1990) have discussed this issue. While the former emphasized subjectivity, the latter focused on integrity between teachers and students. Hooks also strongly advocates paying attention to the process of teacher practice. Teachers should strengthen their spiritual contentment so they can stimulate students to think further about their own situation, environment and social relationships. They would then be willing to change an unfair/unreasonable social reality.

During their visits, students learned how citizen journalists operate. They listened to the needs of disaster 
victims and shared their experiences. Thus, students gained an understanding of the commonality of the events/issues. As Hooks (1990) suggests, students can learn how to think critically and analytically when they explore the reality of their lives, especially their common cultural experiences. As a result, their participation becomes deeper. Because of their empathy with local people, especially after an ecological catastrophe that highlighted public policy deficiencies, students were led to introspect and thus the goal of awakening critical awareness was accomplished.

The change and action teaching method - Freire (2003) has emphasized that the purpose of developing critical awareness is to enable the oppressed to change the oppressors through action practice. At the end of the course, students' action related to the observed issues. The course proceeded as follows:

Select an issue as an individual and within a group

Independent planning

$\nabla$

Analysis and strategy planning: interviews, characters or narration

Strategy implementation and reflection on the collected data's meaning

Compose the report's first draft based on the inverted triangle structure of a television news topic and organize the paragraphs.

Peer assessment: peers provide feedback and hold discussions with each other

By posting their work on YouTube, Facebook and citizen journal platforms, students had an opportunity to assess the media and to present multiple perspectives, thereby completing the introspective reporting process.

\section{Data Analysis and Evaluation}

\subsection{Stage one: Understanding the right to communicate}

Knowledge and awareness of the right to communicate - At the beginning of the semester, even students from the Department of Communications had little awareness about the right to communicate. Many of them only knew the literal meaning of the phrase. Therefore, the teacher needed to guide and inspire them to better understand what this right and power entailed:

- Teacher: Have you recently encountered any unfair situation?

- Student 1: Our school hasn't built a parking canopy in the parking lot!

- Student 2: Yeah! How long have we waited? Our school doesn't want to build it. It has been so many years.

- Student 3: There is no use reflecting on the problem! Because we are students, no one wants to take charge.

- Student 2: It's no use ... a waste of time! No use complaining!

During this stage - the second week of the course - few students were willing to talk, with most remaining silent. The suggestion of constructing a parking canopy in the school became a discussion topic. Because of the proximity effect, many students began to connect this issue to their rights. However, when taking further action 
was discussed, most students lacked confidence and responded negatively. The students were used to under-estimating themselves and were unwilling to face an issue or fight for a right.

The teacher subsequently asked the following questions: "What can you do?", "Would you prefer to have your motorcycle damaged by the sun and rain?", "Have you ever thought about the right to have a parking canopy?", "Do you have the right to own a parking canopy?", "Or do all the things need to be decided by our school?", "What is the reason behind our school's refusal to build the parking canopy?", This was in the third week of the course:

- Student 1: The school is afraid of spending money.

- Student 2: What kinds of rights do we have? It is not as easy as the teacher described. Student 3: Yeah! Those people are all bureaucrats. Each time they say yes, but then nothing happens...

- Student 4: However, because the motorcycles are ours, we have the power to ask the school to do it. Doesn't the principal say that students are the owners of the school?

During the discussion, student 4 asked: "Doesn't the principal say that students own the school?" Evidently, the student had some basic understanding of students' rights. Others did not have this because no one had previously questioned the school's decisions. In these circumstances, they judged the school in a negative way. This stage confirmed Freire's viewpoint: knowledge and information should be sufficient to open up the possibility of criticism. Even though there was a small group of students who understood this issue in relation to their own rights, knowing how to act was another issue. Limited by the amount of information they could access, most students only superficially discussed and evaluated the issue. They could not determine what kinds of action to take.

With respect to the right to communicate, students gradually evolved an understanding of the relationship between power and their rights. During the fourth week this discussion happened among students:

- A: The right to communicate is the right that television stations have to broadcast, right?

- B: The right should mean power. Is that correct?

- A: Then, the Internet can be one of the media as it can be used to broadcast too. B: Broadcast what?

- A: Like news. ...

The discussion highlighted the deficiency in their knowledge. According to Freire (2003), criticism is grounded in a pre-existing knowledge base and the criticism would enable the acquisition of power. Here, the students discussed at random without first preparing. The teacher modified the teaching method. Before the in-class discussion, the teacher had the students seek out information that they could then discuss. The discussion that followed focused more on the issues, but students still lacked an active understanding of citizen knowledge or public issues and the depth of critical thinking was limited.

Equipping students with communication knowledge to awaken their critical awareness - Knowledge is the foundation of criticism. Students can identify and understand questions and can even provide a critique of issues based on their continuous data collection. Equipped with knowledge, they can challenge unfair and unreasonable ideological control within society or the media. Analyzing media content was, therefore, an indispensable course component. The teaching materials' focus was successful because it connected to students' life experiences.

As far as I am concerned, the current situation in Taiwan has nothing [to do] with whether it is suitable or not. Since bureaucracy is endless, what we see is what the bureaucracy expects us to see, rather than what we should see. In such circumstances, there are many reports which take words and phrases out of [context] ... and stir up trouble. (Student J's introspection journal)

This case confirms Livingstone's (2004) argument that the audience is controlled by a distinct ideology manifested in the media's operation. The question is who makes the audience see certain kinds of content, or not see certain kinds of content? Who has power to control media content? When students become aware of the power structure operating the control of media content, this signals the awakening of critical awareness: 
Many television stations have a so-called online call. Usually I doubt the credibility of the unexamined content and whether it can be broadcasted. Media is the fourth power which should not be manipulated. (Speech record sheet of Student Z)

With many available examples from the reporting of weekly news, Student $\mathrm{Z}$ started to question what the fourth power was.

The following example shows students' recognition of the importance and function of the fourth power. Moreover, they demonstrated an understanding of the journalists' role:

Journalists' reports should supervise our government and show citizens' dissatisfaction. They should not follow what the government has said. (The speech record sheet of Student I)

Here, "supervise" means the public service-oriented role of journalists. The role should entail revealing proposed governmental decisions that citizens would consider worth examining. Student I had some expectations and recognition of the journalists' role. Additionally, the student expected journalists to function in a forthright manner.

As far as I am concerned, it is the supervisor of the media industry who should be concerned about fairness in reporting. I think attitude is important. If I can be a journalist in the future, I don't want to be a person like this. I should like to be an individual reporting news independently rather than being affected by external factors. (Student I's introspection journal)

Phrases like "the supervisor ... fairness in reporting", "I don't want to be", and "individual reporting news independently" demonstrate Student I's understanding of the problem within the media structure. Media institutes affect and control journalists' reports. Therefore, with respect to fair reporting by the media, Student I insisted that an individual should report news independently from the mainstream media. This could lead to fairer reporting. The critical awareness comes naturally from what is discovered during a discussion and then experienced (Shor, 2012).

\subsection{Stage 2 Awakening of critical awareness}

Based on the teacher-guided visit to meet Alishan tribe members, and the citizen journalism seminar organized to elicit the participation of local people, students were finally able to witness the restoration process in the disaster-struck areas and the river diversion caused by the typhoon. They emotionally experienced a catastrophe that affected their hometown. Thus, the connection between theory and practice brought academic knowledge and information into students' actual lives (Hook, 1994).

Our government has already built some prefabs for them. What other problems do they have? Do they ask [for] too much? (...) I think I am only a student. This should be the thing belonging to adults. It is a little bit beyond me. Besides, I don't know what happened in the mountains. I have no opinions... (Student H's statement during the course discussion)

Words and phrases such as "I have no opinions" and "What other problems do they have?" reflected immediate responses when students could not relate to the situation. Critical awareness was generally absent; as students felt that the situation had no relevance for them. However, their trips and frequent experiences of sharing (Shor, 2012) changed their viewpoints by the end of the semester.

After going to Alishan, I feel that I will ask questions if I have the chance to do this in the future ... For example, how effective is the repair work? What is the learning environment of children? How are mountain products transported? Also, the destruction of tourism... They have already mentioned that the most serious problem concerns their livelihoods. (In-depth interview of Student H) 
Is there any need to regulate the river's highland beach? The Morakot disaster destroyed the original four basketball scoreboards and roller fields on the river highland beach. The original purification tank has been covered under the river highland beach. How can the government deal with the aftermath? This is a big problem. After I visited the place, I realized that this was the problem. (In-depth interview of Student I: critical awareness/change, May 15, 2010)

Other students had similar reactions in the interviews at the end of the course:

The Bazhang River event was in the news in July 2000. What was different after the debate? After ten years, the problem of sand accretion is still there. What has our government done? I don't understand. (Student Q)

It has been a year since the Morakot disaster. What is the situation regarding the Fu Weng Bridge now? (Student B)

Yeah! I found a rule saying that there should be no gravel pits within 100 meters of rivers. However, there were obviously gravel pits under the Fu Weng Bridge. Was the dam for sand collection? Did it protect or destroy the river?" (Student $\mathrm{L}$ )

The phrases "What has our government done?", "What did they modify?", "What is the situation?", "protect or destroy the river", and "the most serious problem concerns their livelihoods" indicate students' deep reflections. Students realized that the local people were concerned about their livelihoods through experience-sharing. Several students began to learn about the problems as they gained an understanding of the actual situation and of what the local people wanted. The development of their critical awareness and its effects was revealed in their life experience, as emphasized by Hook (1994).

\subsection{Stage Three: Citizen Action in Practice}

In the early weeks of the course, students became aware of problems and inequities but lacked any notion of what they could do:

Actually, there are many unfair things. There are no truly fair things in the world. I don't know what to do. After all, we are just students. (Student K during the course discussion)

Actually, the problems discussed in the course are not things that we can solve ... our government also rebuilt for them. (Student J's introspection journal: questions/awareness, March 2010)

And there is evidence that the course was changing their perspective:

Some issues about the media-actually I hadn't considered them before this course. It is not because I have no idea, but because I never thought about them. (Student K's introspection journal: questions/awareness, March 28, 2010)

However the phrases "don't know what to do", "are not the things that we can solve", "this is a natural disaster, "I have no idea", and "I never thought about them" demonstrated that students were at the initial stage, and most students had not paid much attention to public issues. During this stage, a deficiency in critical awareness was apparent, but because of their site visit, most students developed a better understanding about the problems in the disaster-struck areas.

In the last phase of the course, students began to change:

After visiting the disaster areas, I found that the people needed us. They needed us to speak for them. (In-depth interview of Student D) 
They then developed their own reports and published them and reflected on the impact: On the People Citizen Journalism website, Public Television, UNT.com, our school's website, YouTube, or the print media, we can see and hear what the victims think and are concerned about. Though we took only one course, we helped them. (In-depth interview of Student L)

I will never think I am small again. Actually, through mass communication, there is huge power which I never thought about before. ... (In-depth interview of Student H: action/change, May 15, 2010)

The words, "need us", "we helped them", and "never think I am small" represent assumptions of journalistic and communication roles among students, and indicate an awareness of citizen recognition and power. However, for change and action awareness to occur, a thorough transformation supported by real action is required. This remains difficult. While the teacher could provide guidance during the course, after class finished, this environment was lacking. Thus, motivation to change and recognition of action were absent, making habituation in daily life a challenge:

\begin{abstract}
I think after the class I will not have the chance to be concerned about the issues because the situation is different. Maybe I will be too busy that I will forget them. Not because I don't care anymore, but because of lack of guidance from the teacher and classmates (...) I am still too small. I don't think our government would do anything after we report the problems. The issues not only need to be seen by the government, but they also need their action ... (Student F's introspection journal)
\end{abstract}

The words "too small", "change of circumstance", and "not only need to be seen... but they also need their action", showed that this student still seemed somewhat reticent regarding real change and practice; such practice may or may not become a habit in real life. Though there was recognition in the awareness with changing circumstances after the class, only those who were strongly motivated could maintain their passion to engage in actions relating to public issues. Real practice is largely based on past expectations of the government and experience, and many students mistrust governmental agencies. Though a course cannot raise all students' willingness to participate in actual practices, it significantly increased their critical awareness of public issues and led to citizen action during the course. The longer term effects cannot be evaluated without a longitudinal study which is beyond the researcher's current scope.

\title{
5. Conclusion and Recommendations
}

The course demonstrated a student-centered teaching strategy that awakened students' critical awareness. The course discussions at the beginning and end of the semester indicated that most students gradually developed a basic level of critical awareness. As emphasized by Freire, critical awareness should be awakened to create the possibility of practice. From an analysis of the data, it is evident that a change occurred in students' critical awareness and their recognition of the meaning of action. However, in practice, because most students had been affected by their peers and oppressed by a cramming-oriented education system, they were disconnected from the issues. They were not motivated to act or practice. Even though they were aware regarding practice (when critical awareness was awakened), this was not their first priority. However, without critical awareness, there can be no change or action. The cultural belief in "hoeing one's own potatoes" affected students deeply. According to Hooks, students' learning should be acquired imperceptibly and should continue into their daily lives. Changes in individual practices are limited by ingrained values. As theorized by Freire, Shor and Hooks, the depth of critical awareness that is acquired may be connected to collective changes and action practices.

\section{References}

Bazalgette, C. (1997). An agenda for the second phase of media literacy development. In R. Kubey (Ed.). Media literacy in the information age (Vol. 6, pp. 69-78). New Brunswick. NJ: Transaction. 
Wang, H. L.

Bonser, S. A., \& Grundy, S. J. (1988). Reflective deliberation in the formulation of a school curriculum policy. Journal of curriculum Studies, 20(1), 35-45. https://doi.org/10.1080/0022027880200103

Brown, J. A. (1991). Television "critical viewing skills" education: Major media literacy projects in the United States and selected countries. Hillsdale, NJ: Lawrence Erlbaum.

Brown, J. A. (1998). Media literacy perspectives. Journal of Communication, 48(1), 44-57. https://doi.org/10.1111/j.1460-2466.1998.tb02736.x

Buckingham, D. (1990). Watching media learning: Making sense of media education. London: The Flamer Press.

Carr, W., \& Kemmis, S. (1986). Becoming critical: Education, knowledge and action research. Lewes, Sussex: Falmer Press.

Chang, Y. K. (2010). Environmental justice in the discourse of critical pedagogy. Educational Review, 35, 1-30.

Cheng, M. C. (2012). Instruction for critical approach on media literacy. Curriculum \& Instruction Quarterly, 15(1), 67-90.

Consdiine, D. M., \& Haley, G. E. (1999). Visual message: Integrating imagery into instruction. Englewood, CO: Teacher Ideas Press.

Duran, R. L., Yousman, B., Walsh, K. M., \& Longshore, M. A. (2008). Holistic media education: An assessment of the effectiveness of a college course in media literacy. Communication Quarterly, 56(1), 49-68. https://doi.org/10.1080/01463370701839198

Freire, P. (2003). Pedagogy of the oppressed. New York: Continuum.

Giroux, H. (1988). Teachers as intellectuals: Toward a critical pedagogy of learning. Bergin \& Garvey.

Giroux, H. (1994). Disturbing pleasure. Learning popular culture. New York: Routledge.

Hooks, B. (1990) Yearning: Race, gender, and cultural politics. Boston: South End Press.

Hooks, B. (1994). Teaching to transgress: Education as the practice of freedom. New York, NY: Routledge.

Jenkins, H., Clinton, K., Purushotma, R., Robison, A. J., \& Weigel, M. (2006). Confronting the challenges of participatory culture: Media education for the 21st century. Chicago, IL: The MacArthur Foundation.

Kitchener, R. F. (1986). Piaget's theory of knowledge. New Haven: Yale University Press. https://doi.org/10.2307/j.ctt1xp3sbd

Kubey, R. (1998). Obstacles to the development of media education in the US. Journal of Communication, 48(1), 58-69. https://doi.org/10.1111/j.1460-2466.1998.tb02737.x

Livingstone, S. (2003). The changing nature and use of media literacy. Retrieved from http://www.lse.ac.uk/collections/media@1se/pdf/Media@1seEWP4_july03.pdf

Livingstone, S. (2004). Media literacy and the challenge of new information and communication technologies. The Communication Review, 7, 3-14. https://doi.org/10.1080/10714420490280152

Masterman, L (1985). Teaching the media. London: Routledge.

Masterman, L. (1980). Teaching about Television. London: Macmillan. https://doi.org/10.1007/978-1-349-16279-6

Masterman, L. (1997). A rationale for media education. In R. Kubey (Ed.), Media literacy in the information age (pp. 15-68). New Brunswick, NJ: Transaction.

McKernan, J. (1991). Action inquiry: Studied enactment. In E. Short (Ed.), Forms of curriculum inquiry (pp. 309-326). Albany, New York: State University of New York Press.

McKernan, J. (1996). Curriculum action research: a handbook of methods and resources for the reflective practitioner (2nd ed.). London: Kogan Page.

Meyers, C. (1986). Teaching students to think critically: A guide for faculty in all disciplines. San Francisco: Jossey-Bass.

Miles, M. B., \& Huberman, A. M. (1994). Qualitative data analysis: An expanded sourcebook. Thousand Oaks, CA: Sage Publications.

Noffke, S. E., \& Brennan, M. (1988). The dimensions of reflection: A conceptual and contextual analysis of cybermohalla from India. In K. Tyner (Ed.), Media literacy: New agendas in communication (pp. 11-27). New York, N.Y.: Routledge.

Shor, I. (2012). Empowering education: Critical teaching for social change. Chicago: University of Chicago Press. https://doi.org/10.1177/002205748716900303 
Education for Critical Citizen Action: An example from a course on 'Media and Society'

Shor, I., \& Freire, P. (1987). What is the" dialogical method" of teaching? Journal of Education, 169(3), 11-31.

Stice, J. (Ed.) (1987). Developing critical thinking and problem solving abilities: New directions for teaching and learning. San Francisco: Jossey-Bass.

Tsai, C. T. (2004). Curriculum action research: A handbook of methods and resources for the reflective practitioner. Kaoshiung: Liwen Publishing Group.

Tsai, C. T. (2011). Competence: DNA of curriculum reform. Taipei: Higher Education.

Wu, C. Z., Chen, S. M. (2007). Media literacy education. Taipei: Liwen Publishing Group.

Young, R. (Ed.). (1980). Fostering critical thinking: New directions for teaching and learning. San Francisco: Jossey-Bass.

Zeichnerk, K. M., \& Liston, D. P. (1987). Teaching student teachers to reflect. Harvard educational Review, 56(1), 23-48. https://doi.org/10.17763/haer.57.1.j18v7162275t1w3w 
Wang, H. L. 